Article

\title{
Students' Perceptions of the Actual Use of Mobile Learning during COVID-19 Pandemic in Higher Education
}

\author{
Uthman Alturki *(D) and Ahmed Aldraiweesh (iD) \\ Educational Technology Department, College of Education, King Saud University, P.O. Box 65663, \\ Riyadh 11566, Saudi Arabia; aaldriwish@ksu.edu.sa \\ * Correspondence: ualturki@ksu.edu.sa
}

check for

updates

Citation: Alturki, U.; Aldraiweesh, A. Students' Perceptions of the Actual Use of Mobile Learning during COVID-19 Pandemic in Higher Education. Sustainability 2022, 14 , 1125. https://doi.org/10.3390/ su14031125

Academic Editors: Javier Cifuentes-Faura, Joseph Crawford and Jo-Anne Kelder

Received: 13 December 2021

Accepted: 13 January 2022

Published: 19 January 2022

Publisher's Note: MDPI stays neutral with regard to jurisdictional claims in published maps and institutional affiliations.

Copyright: () 2022 by the authors Licensee MDPI, Basel, Switzerland. This article is an open access article distributed under the terms and conditions of the Creative Commons Attribution (CC BY) license (https:// creativecommons.org/licenses/by/ $4.0 /)$.

\begin{abstract}
Mobile learning (M-learning) has become a significant component of higher education technology. Moreover, M-learning allows students to study, collaborate, and exchange ideas while using the internet and technology. Furthermore, an acceptance of M-learning is necessary for students and educators when it comes to using M-learning systems. However, in Saudi Arabia, not enough studies have been conducted to address students' perceptions of their actual use of mobile learning for the purpose of education during the COVID-19 pandemic. Therefore, the current research aims to examine students' satisfaction with their behavioral intention to use mobile learning, as well as their perceptions of their actual use of mobile learning during the COVID-19 pandemic in higher education. The research is based on the Technology Acceptance Model (TAM). The satisfaction and behavioral intentions of students to utilize mobile learning to make real use of mobile education was measured using four separate variables. A TAM survey was used to collect the majority of the data, with questionnaires being randomly distributed to 300 students from King Saud University. SPSS and Smart-PLS3.3.3 were used to analyze the data. The results in terms of the students' satisfaction and behavior in using M-learning show that M-learning has a good and constructive influence on the actual usage of M-learning during the COVID-19 pandemic in higher education. As a result, we encourage students to use M-learning in their classrooms and to collaborate with their peers at higher education institutions. The study's empirical findings aid in the integration of the TAM model in order to increase students' M-learning performance.
\end{abstract}

Keywords: TAM theory; educational technologies; COVID-19 pandemic

\section{Introduction}

In times of change, the methods we use to teach and learn must adapt to the changing demands of society. Education is a transformational process which involves using active teaching methods and incorporating technology into the classroom [1]. In particular circumstances such as the COVID-19 pandemic, using online training and mobile telecommunications to conduct the teaching and learning processes is critical [2]. Mobile technologies such as smart phones, provide a variety of features that enhance mobile student learning, such as customized interfaces, timely access to information, context sensitivity, rapid communication, and feedback opportunities [3]. Mobile learning is defined as education via the Internet or networks using personal mobile devices such as tablets and smartphones to obtain learning materials through mobile apps and using personal interactive technology [4]. In the current period of technical advancements, it is evident that technological improvements have an impact on all sectors of society [5]. The use of technology during the COVID-19 pandemic in higher education institutions has grown to encompass the creation of novel learning and instruction methods [5-7]. Students and instructors have been shown to benefit from M-learning, with improved face-to-face and remote student involvement [8]. Several studies have investigated the impact of M-learning on consumer usage $[9,10]$, and many students and instructors have been the focus of 
M-learning [11,12]. Although mobile devices are one of the main tools associated with learning, being entertained, and teaching [13], there are still very few guidelines on the sustainability and transfer of mobile learning initiatives [14]. According to Gikas and Grant [15] there are a number of different ways in which mobile devices are associated with learning, communication, and interaction. The use of groupware for shared displays in M-learning has had an impact on improving face-to-face interactions between peers [16]. The positive impact on their implementation, the increase in student satisfaction (SS), the promotion of student independence, the improvements in system functions, and the enhancement of student interaction were all highlighted by [17]. The use of M-learning applications in collaborative learning contexts has been reviewed by [18]. The results show that the impact of problematic learning pedagogies has been largely positive, such that teachers have increased their trust in other teaching programs and have used them to an increasing extent. Social differences between users are indicated by the application of Mlearning [19]. Shin and Kang [20] found that M-learning offers an opportunity to strengthen interactions and cooperation between students and teachers. They also found that it was extremely important for the organization-student balance and security to be maintained and for copyright problems to be dealt with. According to Hwang and Chang [21], mobile learning significantly improved the students' local cultural identity, learning interests, and learning attitudes. Some educators are experimenting with merging social media apps and mobile technology to better their teaching and learning [22-24]. As a result, mobile technologies and social media play a key role in facilitating and promoting participatory information sharing, interoperability, user-centered design, and collaboration through social software, content sharing, tagging, social networking, blogs, wikis, and RSS $[25,26]$. Others, on the other hand, might use social media for activities such as interaction with students (professional/Facebook/Blog), making calls (Skype), and test/quiz/calendars/SMS [27]. Some students, on the other hand, can explore adopting mobile applications for learning, calendars, uploading learning materials, peer discussion, file sharing, and tests and quizzes [28]. To effectively engage students with feedback, we used mobile technology and social media available on these technologies, which students already use on a regular basis $[29,30]$. This is because skillfully designed mobile learning activities may entice students to participate in them [31], transforming them from passive to active learners [32]. However, given the suddenness and novelty of the circumstance, using mobile learning through social media will have more detrimental than beneficial effects on pupils [33]. For example, because of the pervasive and social character of mobile social media, students may communicate with one another at any time and check their friends' posts on the same platform that they study on. However, there are still technical and non-technical barriers to overcome, particularly for students' use and uptake of M-learning [34]. M-learning is still a problem, according to research $[35,36]$. Furthermore, present academics and mobile carriers lack a good understanding of M-learning customers' wants and expectations. Acceptance of M-learning by students is, in fact, a vital step toward securing the system's effective implementation in higher education [37,38]. As a result, comprehension and identification are critical variables in students' acceptance of M-learning systems. Furthermore, the time and effort necessary for the implementation of any information system for its deployment is costly. Information system researchers are continually trying to figure out what elements impact a system's adoption in order to ensure its sustainability viability [39-41]. Valencia-Arias et al. [42] found that both teachers and students favored M-learning for education. Therefore, these results can help university students to understand the impact of M-learning on their academic performance. Moreover, this study's major objective is to investigate the usage of M-learning, as well as students' perceptions of its actual use and its impact on their education. The study identifies the main drivers for M-learning regarding students as a way to improve M-learning for training purposes. A broader model of TAM, based on the M-learning literature during the COVID-19 pandemic in higher education, has been developed to achieve these objectives. M-learning is the basis of the TAM model. However, no prior study in Saudi Arabian higher education has looked at 
students' opinions regarding M-learning and their aspirations to use it for digital learning. As a result, the goal of this study was to create a new model and conduct confirmatory factor analysis to understand more about how students in Saudi Arabia's higher education use M-learning.

\section{Hypotheses and Model Development}

The influence of M-learning on personal innovativeness, task technology fit, and student satisfaction was demonstrated in this study using the model illustrated in Figure 1. The relationships between personal innovativeness, student satisfaction, task technology fit, and behavior intention to use M-learning are as shown in Figure 1. Figure 1 also illustrates the relationship between personal innovativeness and student satisfaction, task technology fit and intention to use M-learning, perceived usefulness and perceived ease of use for M-learning in the context of student satisfaction. This study created 11 hypotheses based on previous studies related to the TAM model [43,44], as to how M-learning might affect student satisfaction and behavior intention to use M-learning during the COVID-19 pandemic in higher education. Furthermore, frameworks suggesting M-learning acceptance are based on a transient feature, and their influence on higher education issues has not been explored. The goal of this study is to determine the important properties of the TAM model for learning during the COVID-19 pandemic at King Saud University. The scenario is as depicted in Figure 1.



Figure 1. Research model.

\subsection{Personal Innovativeness (PI)}

The influence of information system adoption on personal innovativeness on information system adoption is a key factor $[45,46]$. The more receptive to new technologies and inventive consumers are, the more sensitive they are. In summary, more inventive users are more likely to embrace new technology $[47,48]$. Because many individuals are still unable to use many sorts of mobile services, PI plays a key part in their desire to use mobile learning $[49,50]$. As a result, PI is expected to have a favorable influence on the SS and $\mathrm{BI}$ in terms of mobile learning uptake. 


\subsection{Task-Technology-Fit (TTF)}

According to Goodhue and Thompson [51], Task-Technology-Fit (TTF) functionality is only equipped with features for feasibility when people accept technology [51,52]. Although valuable technology can be observed, its performance cannot be improved if the task in hand [53]. M-learning technology is frequently created to help users complete various learning activities efficiently. Therefore, acceptance of M-learning by combining various technology-based fitness approaches is important in order to create tailored tasks. The degree of TTF can evaluate how well an operating system matches the satisfaction level of the individual [51,54]. TTF involves the association of task needs, individual skills, and functions of the mobile technology system [55]. TTF is also linked to personal performance criteria in the larger context of considering the impact of IT on individual performance $[51,56]$.

\subsection{Perceived Ease of Use (PEU)}

Perceived ease of use is defined as "the degree to which a person believes that using a particular system would be free of effort" [43]. When students use an M-learning system on their mobile device for educational reasons, PEU is related to the extent to which they experience less challenging or complicated circumstances in the academic context. In the context of M-learning, [11] defined PEU as the ease with which a customer can utilize M-learning. When instructors utilize M-learning, even if they do not use the Mlearning platform, their workload increases [11]. According to [43], attitudes, perceptions of usefulness, and behavioral intentions in the early phases of system adoption might be influenced by the concept of a difficult-to-use information system $[57,58]$.

\subsection{Perceived Usefulness (PU)}

Davis et al. [43] says that the PU is based on how much a person believes his work performance can be improved when using a given system [43]. Students defined their belief in mobile methods of learning when it comes to adapting their performance as PU. This study defined the concept of improving teacher performance in areas of technology as PU [43]. The PU of M-learning promotes good behavior intention to use M-learning and improves the use of M-learning on the part of students and trainers [43,59]. According to [43], the PU affected the initial information system TAM, and the perceived attitude and purpose, according to recent M-learning research $[57,60], \mathrm{PU}$ is a good predictor of both SS and BI [61].

\subsection{Students' Satisfaction (SS)}

Students' satisfaction (SS) with regard to information systems refers to student users' perceptions of how well the system has satisfied their expectations and met their demands [57,62]. The perception of an individual's wants, objectives, and desires, as well as that person's overall vision of the IS, is characterized as SS [63,64]. It is important to remember that user satisfaction relates to how happy users are with their information systems and the assistance they receive $[65,66]$. A lot of students found that people are happy with their plans to utilize e-learning services [67]. Improved user satisfaction helps increase user intention to use [20]. Satisfaction was also found to have a significant beneficial impact on successful utilization [17]. Hassanzadeh et al. [67] found that satisfaction had a favorable influence on actual usage of the e-learning system. As a result, both BI and the actual usage of M-learning were predicted to be favorable in this study.

\subsection{Behavioral Intention to Use (BI)}

Behavioral intention to use refers to an individual's desire to carry out a specific action [68]. BI has been linked to the adoption and usage of a certain technology [43,69]. According to TAM, behavioral intention to use is the most effective predictor of real system usage, and the theory of reasoned action (TRA) is the most effective predictor of actual system use [70]. For students to assess M-learning acceptability, the BI is likewise regarded 
as the most essential component of acceptance technology [71]. In addition, M-learning studies have demonstrated that the BI has a favorable influence on M-learning usage [17,72].

\subsection{Actual Use of Mobile M-Learning (AUM)}

M-learning was not often considered in TAM research before Davis et al. [43] and Sánchez-Prieto et al. [57], as the evaluation of a structure was unclear. In general, subjective, and objective metrics can be used [73]. The former must ensure that data from system logs, logins, and system commitments [74] is monitored. The latter is concerned with the self-reported use of students' technology, which can be affected by response distortions according to a recent study, the actual use of mobile M-learning devices in classrooms [75]. This study investigates the nature and scope of the link between long-term M-learning and academic achievement.

\section{Research Methodology}

\subsection{Study Design}

Mobile learning (M-learning) is education (learning) through social media using personal mobile devices, such as tablets and smartphones to obtain learning materials through mobile apps, social interactions, and online educational hubs. It is flexible, allowing students/learners access to education anywhere, anytime [76,77]. Therefore, the current research aims to examine students' satisfaction with their behavioral intention to use mobile learning, as well as their perceptions of their actual use of mobile learning through social media during the COVID-19 pandemic in higher education. To achieve this purpose, we distributed a survey to present findings on how students at King Saud University utilize social media for teaching and learning. To efficiently meet the research aims, the study's analyses were divided into two sections. The initial stage was to collect data from university students via a questionnaire. The study looked at how M-learning affects through social media in higher education, as well as attitudes about and actual use of M-learning through social media. Students in higher education were undergraduates and graduates from universities in this survey. Respondents were from diverse IT school fields, including information systems and management, engineering, and social science. Some of the people that are now utilizing the M-learning system through social media: participants in the study may be able to assist us in answering the survey's questions in this respect. A five-point Likert scale was utilized in the poll. This Likert scale [78] is said to be more accurate than the five-point Likert scale. Our investigation progressed to the next level. Structural Equation Modeling Smart-PLS3.3.3 and SPSS were used to analyze the data. The structural model proposed for this form [79] was used to examine construct validity, convergent validity, and discriminant validity. Actual usage of M-learning through social media was one of the study's main endogenous constructs. Figure 1 depicts the suggested model which consists of seven components, namely PI, TTF, PEOU, PU, SS, BI, to use, and AUM. Eleven path lines were proposed for the seven constructs; two path lines were proposed for PI, TTF, PEOU, PU, SS, and one path line was proposed for BI, all hypothesized to significantly predict seven constructs (Figure 1).

\subsection{The Instrumentation}

A survey instrument was adopted to achieve research aims through an in-depth analysis as shown in Table 1, there were seven constructs involving thirty-five indicators. Personal innovativeness (PI) was proposed with the establishment of five items as recommended by [80]. Task-technology fit (TTF) was proposed with the establishment of five items as recommended by [52]. The concept of perceived ease of use (PEU) was presented, along with the development of five elements as suggested by experts $[2,81]$. The concept of perceived usefulness (PU) was presented, along with the creation of five elements as suggested by $[2,81]$. The establishment of five elements in terms of student satisfaction (SS) was proposed [81]. The concept of behavioral intention to use (BI) was introduced, with five items as advocated by [2,67]. The establishment of five items suggested by the actual 
use of M-learning (AUM) was proposed with the establishment of five items recommended by the actual use of M-learning (AUM) [81].

Table 1. Demographic profile.

\begin{tabular}{|c|c|c|c|c|}
\hline Items & Description & $\mathbf{N}$ & $\%$ & Cumulative $\%$ \\
\hline \multirow{2}{*}{ Sex } & Male & 262 & 87.3 & 87.3 \\
\hline & Female & 38 & 12.7 & 100 \\
\hline \multirow{4}{*}{ Age } & $18-22$ & 18 & 6 & 6 \\
\hline & $23-29$ & 235 & 78.3 & 84.3 \\
\hline & $30-35$ & 32 & 10.7 & 95 \\
\hline & 36-Above & 15 & 5 & 100 \\
\hline \multirow{4}{*}{ Specialization } & Social Science & 50 & 16.7 & 16.7 \\
\hline & $\begin{array}{l}\text { Science and } \\
\text { Technology }\end{array}$ & 130 & 43.3 & 60 \\
\hline & Management & 103 & 34.3 & 94.3 \\
\hline & Others & 17 & 5.7 & 100 \\
\hline \multirow{3}{*}{ Use_M } & $\begin{array}{l}\text { Several times a } \\
\text { day }\end{array}$ & 240 & 80 & 80 \\
\hline & Once in a day & 43 & 14.3 & 94.3 \\
\hline & $\begin{array}{l}\text { Several times a } \\
\text { month }\end{array}$ & 17 & 5.7 & 100 \\
\hline
\end{tabular}

\subsection{Data Collection and Analysis}

To carry out the study, 300 questionnaires were distributed to students at King Saud University. The TAM model was used to construct a conceptual model for the study in order to track the actual application of the M-learning model in educational institutions. This study examined the students' views of the use of M-learning to determine the extent of SS and to measure the behavioral intention to use mobile learning in a higher education context. This questionnaire was handed out by hand to university students, asking for anonymous comments on the use of M-learning in terms of SS and BI, as well as its impact on the actual usage of M-learning in terms of sustainable learning measures. IBM SPSS Statistics version 26 and Smart-PLS 3.3.3 were used to analyze the data using structural equation modeling. There was a total of 300 surveys returned, $262(87.3 \%)$ of which were from males and $38(12.7 \%)$ of which were from females. A total of $18(6.0 \%)$ of the respondents were between the ages of 18 and 22, $235(78.3 \%)$ were between 23 and 29, 32 $(10.6 \%)$ were between the ages of 30 and 35, and $15(5 \%)$ were between the ages of 36 and above (for details, see Table 1). For data analysis, partial least square-structural equation modeling (PLS-SEM) procedures were implemented. In this study, the Smart-PLS 3.3.3 software was utilized for assessing measurement and structural models. The data validity and reliability were measured during their computation in the measurement model. To examine the validity of the data, we reported convergent and discriminant validity. The convergent validity was reported using the AVE formula, with a value of 0.500 , while the discriminant validity was addressed using the Fornell-Larcker criteria, and cross-loading. Meanwhile, an internal consistency reliability procedure was carried out to report the data's dependability. Both CA and CR are dependability methods; both values should be more than 0.700 . For the assessment model, we reported the significance of the relationship through path coefficient, $\mathrm{t}$-value, and $p$-value.

\section{Results and Analysis}

\subsection{Model for Measuring}

According to Hair et al. [79], four assessments of measurement models for PLS-SEM were encouraged in the form of assessing consistency reliability, discriminant validity, convergent validity, and indicator loadings. 


\subsection{Loadings of Reflective Indicators}

The reflective indicator loadings achieved in SEM should be greater than 0.700 [79]. From the computation undertaken, all loadings were higher than 0.700 . The highest loading referred to personal innovativeness PI4 (0.889), while the lowest loading was achieved by Personal innovativeness PI2 (0.737). Thirty-five indicators were included for the next data analysis process (Table 2).

Table 2. Constructs, Items, CR, CA, AVE.

\begin{tabular}{ccccc}
\hline Construct & Items & CR & CA & AVE \\
\hline Personal innovativeness (PI) & PI 1-PI 5 & 0.916 & 0.884 & 0.686 \\
\hline Task-technology Fit (TTF) & TTF 1-TTF 5 & 0.874 & 0.909 & 0.666 \\
\hline Perceived ease of use (PEU) & PEU 1-PEU 5 & 0.864 & 0.902 & 0.648 \\
\hline Perceived usefulness (PU) & PU1-PU5 & 0.864 & 0.902 & 0.647 \\
\hline Students' satisfaction (SS) & SS 1-SS 5 & 0.880 & 0.912 & 0.674 \\
\hline Behavioral intention to use (BI) & BI 1-BI 5 & 0.906 & 0.910 & 0.669 \\
\hline Actual Use of M-learning (AUM) & AUM 1-AUM 5 & 0.877 & 0.910 & 0.669 \\
\hline
\end{tabular}

\subsection{Internal Consistency Reliability (ICR)}

ICR was implemented to evaluate the consistency of the results across indicators. In the current approach, CA and CR were reported. The ICR values should be between 0 and 1. CA and CR should be greater than $0.700[79,82]$. Table 2 presents the reports with regard to CA and CR. The composite reliability and the CA values for all constructs are sufficient, in that they exceeded the recommended amount. Personal innovativeness had a CA of 0.884 and a CR of 0.916 , task-technology fit had a CA of 0.909 and a CR of 0.874 , perceived ease of use had a CA of 0.902 and a CR of 0.864 , perceived usefulness had a CA of 0.902 and a CR of 0.864 , students' satisfaction had a CA of 0.912 and a CR of 0.880 , behavioral intention to use had a CA of 0.910 and a CR of 0.906 , and actual use of mobile learning had a CA of 0.910 and a CR of 0.877 (See Table 2).

\subsection{Validity of Convergence}

Convergent validity is an issue linked to construct validity in which tests using the same or comparable constructs should be closely connected [79]. The computation of convergent validity is reported in this study (AVE). We applied SmartPLS 3.3.3 to calculate the AVE [79]. Through the algorithm, AVE values should be 0.500 or higher (Table 3). From the computation, all constructs obtained AVE values explaining more than 0.500 of the variances. Personal innovativeness' AVE value was 0.686 , task-technology fit's AVE was 0.666, perceived ease of use's AVE was 0.648, perceived usefulness's AVE was 0.647, student satisfaction's AVE was 0.674, behavioral intention to use's AVE value was 0.728, and actual use of mobile learning's AVE was 0.669 (See Table 3). 
Table 3. Discriminant scale criteria.

\begin{tabular}{|c|c|c|c|c|c|c|c|}
\hline Factors & AUM & BI & PU & PI & SS & TTF & PEU \\
\hline Actual Use of Mobile Learning & 0.818 & & & & & & \\
\hline Behavioral Intention to Use & 0.747 & 0.853 & & & & & \\
\hline Perceived Usefulness & 0.742 & 0.732 & 0.805 & & & & \\
\hline Personal Innovativeness & 0.558 & 0.620 & 0.594 & 0.828 & & & \\
\hline Students' Satisfaction & 0.513 & 0.418 & 0.643 & 0.537 & 0.821 & & \\
\hline Task-technology Fit & 0.790 & 0.716 & 0.742 & 0.674 & 0.530 & 0.816 & \\
\hline Perceived Ease of Use & 0.683 & 0.636 & 0.743 & 0.604 & 0.759 & 0.716 & 0.805 \\
\hline
\end{tabular}

\subsection{Validity on a Discriminant Scale}

The degree to which a construct is empirically different from other constructs is known as discriminant validity. Cross-loadings (see Tables 4 and 5), and the Fornell-Larcker criteria were employed in this work to investigate discriminant validity (See Table 3). According to the Fornell-Larcker criteria, the AVE of a concept should be larger than the shared variance of others [83]. Table 3 demonstrates that the construct values are larger than the shared variances of each construct. For example, perceived usefulness (0.805) outperforms all its shared variations; BI to use M-learning (0.732); and actual use of mobile learning (0.742). The Fornell-Larcker criteria was used to determine discriminant validity. Furthermore, if an indicator loading on a cross-loading is lower than its concept, discriminant validity develops [79].

Table 4. Measures for cross-loading and loading.

\begin{tabular}{|c|c|c|c|c|c|c|c|}
\hline Items & AU & BI & PEU & PI & PU & SS & TTF \\
\hline AUM_1 & 0.808 & 0.777 & 0.545 & 0.481 & 0.601 & 0.343 & 0.589 \\
\hline AUM_2 & 0.830 & 0.489 & 0.488 & 0.371 & 0.584 & 0.445 & 0.622 \\
\hline AUM_3 & 0.856 & 0.526 & 0.492 & 0.395 & 0.574 & 0.422 & 0.595 \\
\hline AUM_4 & 0.828 & 0.543 & 0.535 & 0.457 & 0.582 & 0.413 & 0.644 \\
\hline AUM_5 & 0.766 & 0.642 & 0.699 & 0.539 & 0.670 & 0.480 & 0.763 \\
\hline BI_1 & 0.608 & 0.815 & 0.553 & 0.548 & 0.627 & 0.369 & 0.592 \\
\hline BI_2 & 0.689 & 0.879 & 0.573 & 0.537 & 0.624 & 0.376 & 0.615 \\
\hline BI_3 & 0.637 & 0.866 & 0.520 & 0.491 & 0.625 & 0.331 & 0.584 \\
\hline BI_4 & 0.653 & 0.877 & 0.543 & 0.515 & 0.635 & 0.349 & 0.632 \\
\hline BI_5 & 0.594 & 0.827 & 0.523 & 0.553 & 0.611 & 0.358 & 0.633 \\
\hline PEU_1 & 0.667 & 0.623 & 0.774 & 0.480 & 0.656 & 0.485 & 0.671 \\
\hline PEU_2 & 0.699 & 0.662 & 0.761 & 0.533 & 0.675 & 0.470 & 0.689 \\
\hline PEU_3 & 0.521 & 0.485 & 0.838 & 0.513 & 0.594 & 0.695 & 0.574 \\
\hline PEU_4 & 0.460 & 0.378 & 0.843 & 0.464 & 0.558 & 0.698 & 0.506 \\
\hline PEU_5 & 0.410 & 0.416 & 0.807 & 0.440 & 0.507 & 0.695 & 0.447 \\
\hline PI_1 & 0.467 & 0.464 & 0.607 & 0.805 & 0.505 & 0.570 & 0.547 \\
\hline PI_2 & 0.359 & 0.373 & 0.465 & 0.737 & 0.384 & 0.527 & 0.449 \\
\hline PI_3 & 0.510 & 0.564 & 0.459 & 0.858 & 0.490 & 0.363 & 0.617 \\
\hline
\end{tabular}


Table 4. Cont.

\begin{tabular}{|c|c|c|c|c|c|c|c|}
\hline Items & $\mathrm{AU}$ & BI & PEU & PI & PU & SS & TTF \\
\hline PI_4 & 0.477 & 0.579 & 0.497 & 0.889 & 0.536 & 0.395 & 0.613 \\
\hline PI_5 & 0.487 & 0.576 & 0.462 & 0.843 & 0.533 & 0.367 & 0.554 \\
\hline PU_1 & 0.587 & 0.538 & 0.705 & 0.485 & 0.755 & 0.635 & 0.604 \\
\hline PU_2 & 0.602 & 0.534 & 0.663 & 0.480 & 0.829 & 0.707 & 0.607 \\
\hline PU_3 & 0.596 & 0.607 & 0.496 & 0.430 & 0.795 & 0.392 & 0.565 \\
\hline PU_4 & 0.610 & 0.646 & 0.536 & 0.502 & 0.817 & 0.402 & 0.605 \\
\hline PU_5 & 0.588 & 0.633 & 0.558 & 0.486 & 0.825 & 0.400 & 0.600 \\
\hline SS_1 & 0.420 & 0.376 & 0.747 & 0.442 & 0.592 & 0.785 & 0.463 \\
\hline SS_2 & 0.446 & 0.386 & 0.699 & 0.456 & 0.638 & 0.856 & 0.464 \\
\hline SS_3 & 0.409 & 0.287 & 0.548 & 0.412 & 0.436 & 0.842 & 0.406 \\
\hline SS_4 & 0.412 & 0.337 & 0.571 & 0.462 & 0.484 & 0.835 & 0.424 \\
\hline SS_5 & 0.413 & 0.309 & 0.496 & 0.428 & 0.445 & 0.784 & 0.403 \\
\hline TTF_1 & 0.609 & 0.644 & 0.565 & 0.488 & 0.608 & 0.382 & 0.769 \\
\hline TTF_2 & 0.655 & 0.603 & 0.606 & 0.586 & 0.657 & 0.463 & 0.878 \\
\hline TTF_3 & 0.684 & 0.585 & 0.623 & 0.597 & 0.668 & 0.454 & 0.860 \\
\hline TTF_4 & 0.649 & 0.530 & 0.607 & 0.574 & 0.522 & 0.436 & 0.799 \\
\hline TTF_5 & 0.627 & 0.555 & 0.519 & 0.503 & 0.566 & 0.428 & 0.769 \\
\hline
\end{tabular}

Table 5. Discriminant validity.

\begin{tabular}{|c|c|c|c|c|c|c|c|}
\hline Factors & AUM & BI & PU & PI & SS & TTF & PEU \\
\hline \multicolumn{8}{|l|}{ Actual Use of Mobile Learning } \\
\hline Behavioral Intention to Use & 0.815 & & & & & & \\
\hline Perceived Usefulness & 0.844 & 0.831 & & & & & \\
\hline Personal Innovativeness & 0.621 & 0.692 & 0.676 & & & & \\
\hline Students' Satisfaction & 0.583 & 0.463 & 0.711 & 0.608 & & & \\
\hline Task-technology Fit & 0.798 & 0.704 & 0.851 & 0.766 & 0.600 & & \\
\hline Perceived Ease of Use & 0.777 & 0.720 & 0.853 & 0.690 & 0.753 & 0.827 & \\
\hline
\end{tabular}

\subsection{Structural Model and Collinearity}

The prediction skills of the structural model were tested as part of the evaluation. However, the collinearity value should be acknowledged before presenting the structural model by reporting the variance inflation factor (VIF) values. Notably, the collinearity of the sets of predictors was examined [79]; perceived ease of use as a predictor of behavioral intention to use; and students' satisfaction. Students' satisfaction is predicted in terms of perceived usefulness, personal innovation, task-technology fit, and perceived ease of use (Table 6) [79]; values greater than three are commonly regarded as having multicollinearity issues. All the VIFs are less than 3. 
Table 6. Variance inflation factor (VIF).

\begin{tabular}{|c|c|c|c|c|c|c|c|}
\hline Factors & AUM & BI & PU & PI & SS & TTF & PEU \\
\hline \multicolumn{8}{|l|}{ Actual Use of Mobile learning } \\
\hline Behavioral Intention to Use & 1.212 & & & & & & \\
\hline Perceived Usefulness & & 2.947 & & & 2.822 & & \\
\hline Personal Innovativeness & & 2.014 & & & 1.958 & & \\
\hline Students' Satisfaction & 1.212 & 2.548 & & & & & \\
\hline Task-technology Fit & & 2.065 & & & 2.965 & & \\
\hline Perceived Ease of Use & & 2.719 & & & 2.658 & & \\
\hline
\end{tabular}

\subsection{Structural Model Evaluation}

The path coefficients, $\mathrm{t}$-statistics, and $p$-value were used to assess the significance of all the direct effects or hypotheses in the structural model. Table 7 and Figure 2 show the results of the bootstrapping computation of all factors. Figure 3 shows the outcomes of the bootstrapping computation. Table 7 summarizes the study's findings, including all factors. For the relationship between PI $->$ SS $(\mathrm{H} 1)(\beta=0.149 ; \mathrm{t}=2.757, p<0.001)$, the hypothesis was supported. For the relationship between PI -> BI to Use (H2) $(\beta=0.215$; $\mathrm{t}=3.603, p<0.001)$, the hypothesis was supported. For the hypotheses, H3 and H4 were reported to significantly influence TTF $->$ SS $(\beta=-0.198 ; t=2.353 ; p<0.001)$ and TTF $->$ BI to Use $(\beta=0.227 ; t=3.418 ; p<0.001)$. Hence, the hypotheses were supported. Moreover, the hypotheses, $\mathrm{H} 5$ and $\mathrm{H} 6$ were reported to be significantly influenced between PEOU -> SS $(\beta=0.645 ; \mathrm{t}=8.152 ; p<0.001)$ and PEOU $\rightarrow \mathrm{BI}$ to Use $(\beta=0.212 ; \mathrm{t}=2.662 ; p<0.001)$, hence the hypotheses were supported. The relationship between PU $>$ SS (H7) ( $\beta=0.222$; $\mathrm{t}=2.799, p<0.001)$ indicates that the hypothesis was supported. Moreover, $\mathrm{PU}$ is also a significant predictor for $\mathrm{BI}$ to Use, $\mathrm{H} 8(\beta=0.451 ; \mathrm{t}=6.778 ; p<0.001)$, hence the hypothesis was supported. The hypotheses (H9 and H10) were reported to be significantly influence SS $->$ BI to Use $(\beta=-0.268 ; \mathrm{t}=4.538 ; p<0.001)$ and SS $->$ actual use of mobile learning ( $\beta=0.243 ; t=5.887 ; p<0.001)$, hence the hypotheses were supported. Finally, BI to Use is also a significant predictor for actual use of mobile learning, $\mathrm{H} 11$ ( $\beta=0.645 ; \mathrm{t}=16.399$; $p<0.001)$, hence the hypothesis was supported.

Table 7. Hypotheses testing.

\begin{tabular}{|c|c|c|c|c|}
\hline Path of Hypotheses & Path $(\beta)$ & $t$-Value & $p$ Values & Results \\
\hline Hypothesis 1 (H1). Personal innovativeness -> Students' Satisfaction. & 0.149 & 2.757 & 0.006 & Supported \\
\hline Hypothesis 2 (H2). Personal innovativeness $->$ Behavioral Intention to Use. & 0.215 & 3.603 & 0.000 & Supported \\
\hline Hypothesis 3 (H3). Task-technology Fit -> Students' Satisfaction. & -0.198 & 2.353 & 0.019 & Supported \\
\hline Hypothesis 4 (H4). Task-technology Fit -> Behavioral Intention to Use. & 0.227 & 3.418 & 0.001 & Supported \\
\hline Hypothesis 5 (H5). Perceived Ease of Use -> Students' Satisfaction. & 0.645 & 8.152 & 0.000 & Supported \\
\hline Hypothesis 6 (H6). Perceived Ease of Use -> Behavioral Intention to Use. & 0.212 & 2.662 & 0.008 & Supported \\
\hline Hypothesis 7 (H7). Perceived Usefulness -> Students' Satisfaction. & 0.222 & 2.799 & 0.005 & Supported \\
\hline Hypothesis 8 (H8). Perceived Usefulness $\rightarrow>$ Behavioral Intention to Use. & 0.451 & 6.778 & 0.000 & Supported \\
\hline Hypothesis 9 (H9). Students' Satisfaction -> Behavioral Intention to Use. & 0.268 & 4.538 & 0.000 & Supported \\
\hline Hypothesis 10 (H10). Students' Satisfaction -> Actual Use of Mobile Learning. & 0.243 & 5.887 & 0.000 & Supported \\
\hline Hypothesis 11 (H11). Behavioral Intention to Use -> Actual Use of Mobile Learning. & 0.645 & 16.399 & 0.000 & Supported \\
\hline
\end{tabular}




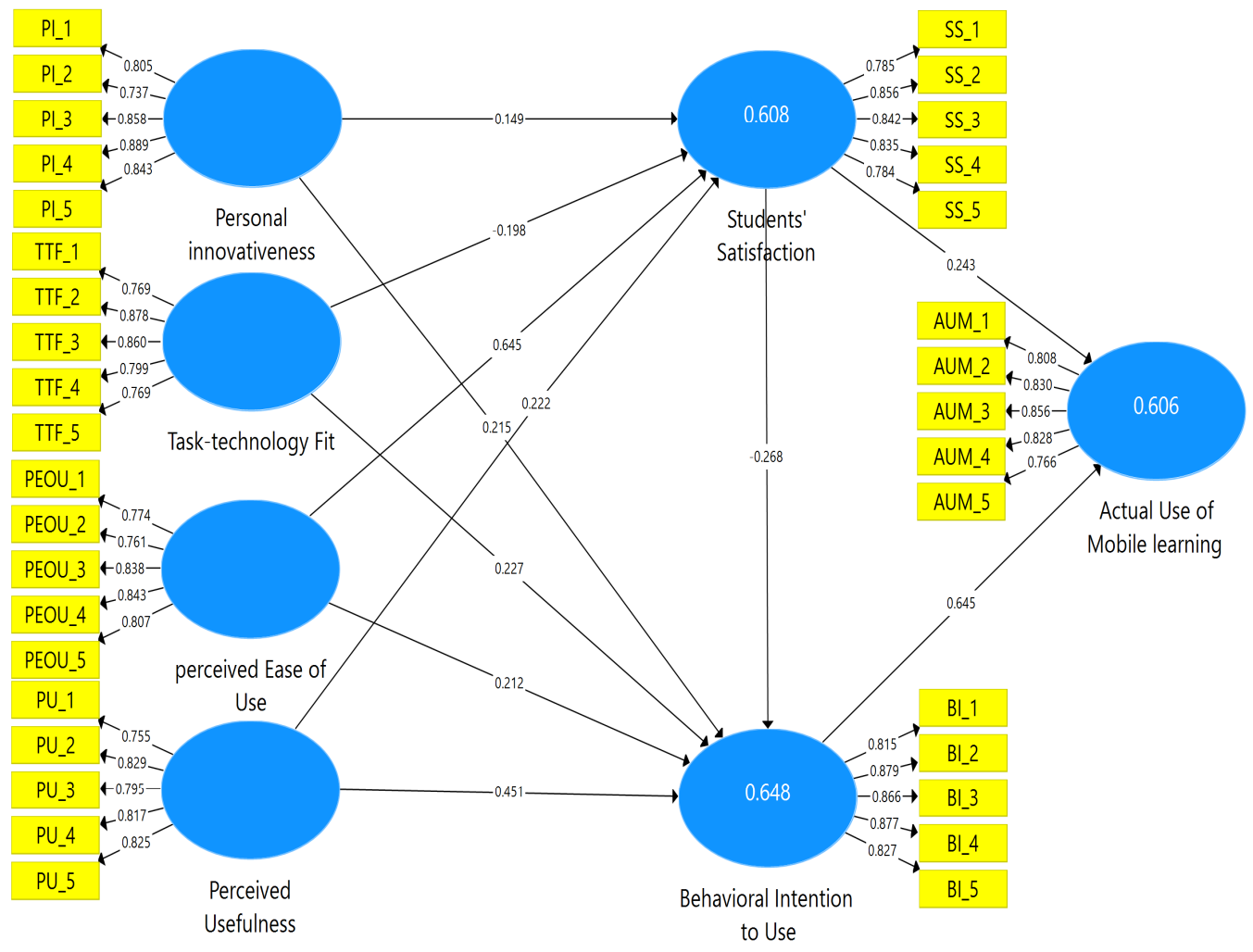

Figure 2. Path coefficient findings.

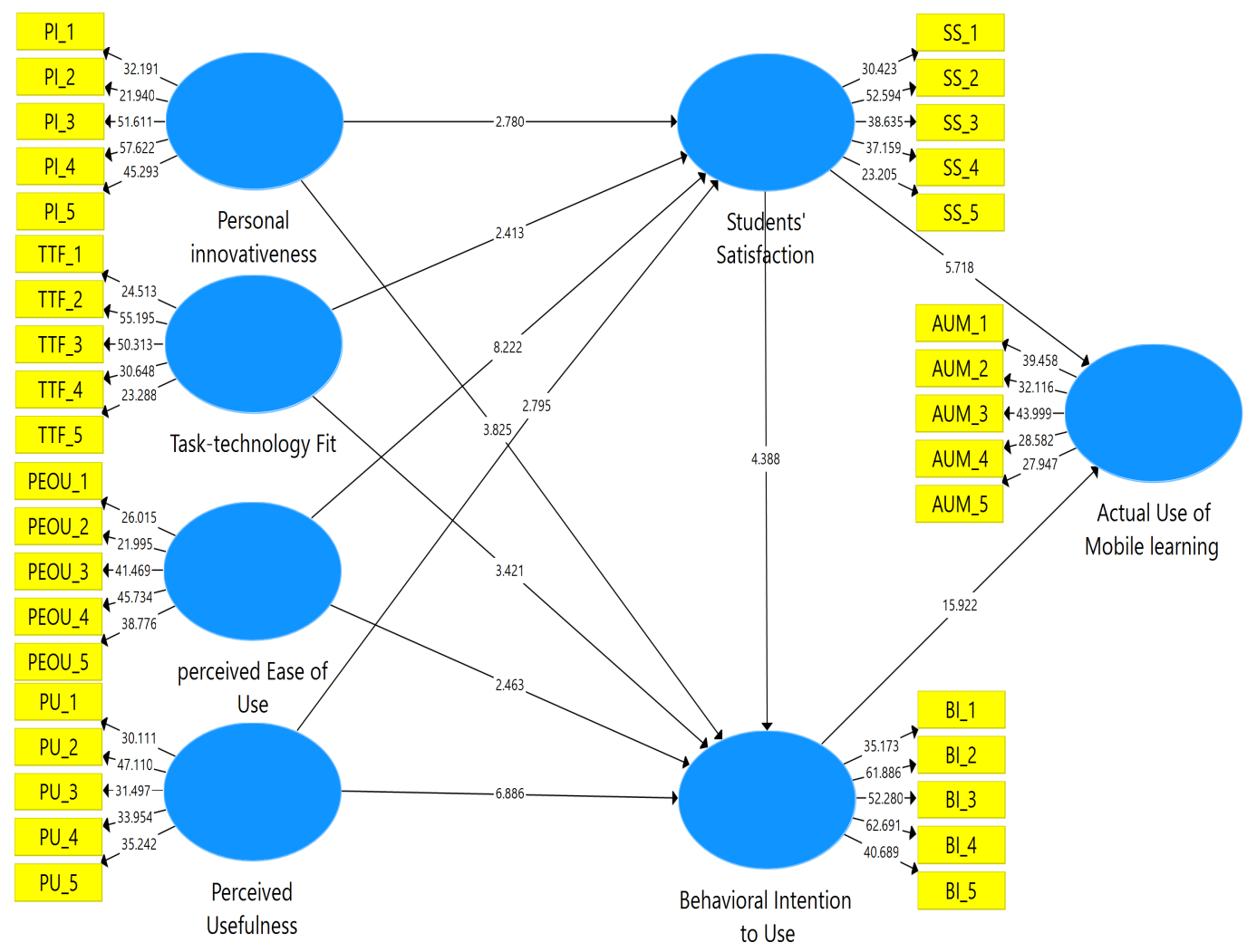

Figure 3. Path (T-values) findings. 


\section{Discussion and Consequences}

The goal of this study is to determine what factors impact M-learning adoption by King Saud University students. The result is a theoretical framework for M-learning based on TAM and two external variables, PI and TTF. A random selection approach for obtaining a sample of King Saud University students was used to test the suggested study framework. The findings are favorably and substantially connected to all the predictors as well as the actual application of M-learning. The regression analysis results and the structural model assessment results are all significant and influence all the factors under consideration. The results indicate that SS and BI are positively affected by PI. The results are compatible with those of Sidik and Syafar [22], Asghar et al. [28] and Issaramanoros et al. [84]. The TTF results show that the SS is significantly influenced and that the students are willing to use M-learning $[59,85,86]$. As a result, students feel that they are better able to see the TTF more quickly when using a mobile device and thus are willing to adopt M-learning. In the context of M-learning, many investigators have studied the importance of PU and PEU [87]. The results of this study support those of other researchers $[60,88]$. The finding of other researchers such as $[25,41]$ also contain two key elements in the educational model of TAM [89]. Students use M-learning to enhance education, the PU, PEU, TTF, and PI. This can be because students use the M-learning version on their computers, so their perceptions about the use of the system are both precise and skewed. These factors are also increasingly convincing about the use of M-learning. Increasing PU and PEU make better use of M-learning because of the nature of the connection. Previous work was performed on the use of mobile phones and technological tools for learning during the COVID-19 pandemic [30,88,90-92], and it has been established that the main structures and explicative variables for the implementation of M-learning systems are the PU, PEU, attitude, social influence, and facilitating conditions [93,94]. The outcomes of this study suggest that students have a good attitude about using mobile learning and social media applications for learning, which is consistent with findings from a study by [93-95]. Students appear to be adjusting their use of mobile devices for studying to meet their specific learning requirements and to improve their overall student learning experience. They use their cellphones' capabilities to execute a variety of mobile learning activities, such as mobile web surfing, reading e-mail, exchanging texts/notes and documents, accessing learning, and reading material, and participating in peer conversation, among others. As a result, instructors have a unique chance to provide their students greater control over how they obtain fast and effective feedback and feed-forward, thereby motivating and engaging them in their studies. As a result, there is a higher integration of the social element into the learning process, which may distract pupils [96]. Furthermore, some teachers provide a wealth of additional resources for their students to study on social media and conduct sessions on weekends and holidays [2,28]. As a result, mobile learning and social media may be regarded useful instructional tools that play important roles in today's educational environment [97]. Refers to a situation in which a person feels overwhelmed by the vast quantity of social demand entrusted to him or her in the context of mobile learning via social media [98]. Students participating in collaborative learning via mobile learning via social media would have an experience [99]. According to this study, six components (PI, TTF, PU, and PEU), SS, and BIM, are critical to M-learning adoption. PI, TTF, and TAM variables have the greatest influence on student university achievement when M-learning is used as an educational approach, according to the research model. In the application of mobile training, mobile-learning BI was the biggest predictor of SS. The modified TAM model partially mediated the influence of all exogenous factors on BI. Student conduct, which affected students' real mobile education usage for educational sustainability, was found to be utilized in this study; its impact on actual mobile learning use was entirely mediated by student behavior. Students supported and intended to utilize M-learning after they were aware of the efficiency and capabilities of mobile devices, the assistance offered to technicians and organizations, and the impact of others. Furthermore, the findings of this study clearly support the real-world use of the variable M-learning system, 
demonstrating favorable impacts on the successful use of M-learning for SS education as well as user's intention to utilize it. According to the findings of this study, subjective enjoyment has a considerable positive influence on perceived usefulness and ease of use. Personal innovativeness, task-technology fit, perceived utility, and perceived ease of use were all used in this study. With the ubiquity of the internet and M-learning for recreational purposes, university students believe their mobile devices to be beneficial and simple to use. As a result, students' enthusiasm for M-learning is expected to rise as the COVID19 epidemic makes it a more common style of learning. M-learning is not only simple to use for kids; it also recognizes the importance of education. As a result, the results demonstrated a high task-technology match in terms of perceived utility and simplicity of use. The findings were confirmed, and both human inventiveness and task-technology fit had a large and direct impact on reported utility and perceived ease of use and online and remote learning as a necessity in times of lockdowns and social distancing due to the COVID-19 pandemic [100]. Therefore, students' satisfaction and behavioral intentions to use M-learning during the COVID-19 epidemic were also affected.

\subsection{Limitations of the Research}

Regardless of the contribution of this investigation, its weaknesses must be dealt with. The limitations of the work have led to limitations in terms of the results of the study. First of all, there is a need for more research in order to increase the number of participants to see whether students from other universities can demonstrate similar results. Second, in addition to the characteristics described in the study, future research should consider several other factors that may influence the desire to utilize mobile learning, such as enabling conditions and social influence.

\subsection{Conclusions and Future Work}

The goal of this study was to use the TAM model framework to evaluate students' views of M-learning. Despite the fact that M-learning has yet to be fully adopted during the COVID-19 pandemic in higher education, the results demonstrate that students believe in its worth, and are willing to accept this new and exciting approach. A thorough review of the literature was used to develop the new model for M-learning in Saudi Arabia's higher education. Seven constructs derived from the TAM model in the form of PI, TTF PU, PEU, SS, and BIM, were the primary contributors to present-day university students utilizing M-learning. Researchers studying M-learning during the COVID-19 pandemic in higher education have yet to investigate student satisfaction and the desire to use M-learning using the TAM approach. As a result, researchers are of the opinion that the TAM model makes a significant contribution, and strongly proposes that universities employ PU, PEU, and PI to encourage students to embrace M-learning for educational purposes during the COVID-19 pandemic. The study also shows that the results are based on the opinions of King Saud University students, which may or may not represent the current global situation. Future researchers should investigate the planning suggestions for PI and TTF, as well as appraising it in terms of its prospective use for education during the COVID-19 pandemic, in light of the widespread usage of M-learning. Future study in this area should consider the perspectives of instructors and other stakeholders during the COVID-19 pandemic in higher education with regard to the usage of M-learning in the classroom. Finally, comparing perspectives from and with other nations can help extend the study's findings and provide us with a better understanding of how prospects of M-learning can be addressed during the COVID-19 pandemic in higher education.

Author Contributions: Conceptualization, U.A. and A.A.; methodology, U.A. and A.A; software, U.A.; validation, U.A. and A.A.; formal analysis, A.A.; investigation, U.A.; resources, U.A. and A.A.; data curation, U.A. and A.A.; writing — original draft preparation, U.A. and A.A.; writing-review and editing, U.A. and A.A.; visualization, A.A.; supervision, U.A.; project administration, U.A.; funding acquisition, U.A. and A.A. All authors have read and agreed to the published version of the manuscript. 
Funding: This research was supported by Researchers Supporting Project in King Saud University, Riyadh, Saudi Arabia.

Institutional Review Board Statement: Ethical review and approval were waived for this study due to this research adopted a questionnaire from previous research. Please refer to Section 3.2, Instrumentation. Also, we distributed the questionnaire to the students we teach, as well as other classes at the same university. Therefore, all the students who answered the questionnaire agreed once they responded. And those who did not agree to respond to the questionnaire were excluded.

Informed Consent Statement: Informed consent was obtained from all subjects involved in the study.

Data Availability Statement: Not applicable.

Acknowledgments: The authors acknowledge the Researchers Supporting Project number (RSP2021/159), King Saud University, Riyadh, Saudi Arabia.

Conflicts of Interest: The authors declare no conflict of interest.

\section{References}

1. Martin, S.; Lopez-Martin, E.; Lopez-Rey, A.; Cubillo, J.; Moreno-Pulido, A.; Castro, M. Analysis of New Technology Trends in Education: 2010-2015. IEEE Access 2018, 6, 36840-36848. [CrossRef]

2. Al-Rahmi, A.M.; Al-Rahmi, W.M.; Alturki, U.; Aldraiweesh, A.; Almutairy, S.; Al-Adwan, A.S. Exploring the factors affecting mobile learning for sustainability in higher education. Sustainability 2021, 13, 7893. [CrossRef]

3. Sung, Y.-T.; Chang, K.-E.; Liu, T.-C. The effects of integrating mobile devices with teaching and learning on students' learning performance: A meta-analysis and research synthesis. Comput. Educ. 2016, 94, 252-275. [CrossRef]

4. Pedro, L.F.M.G.; de Oliveira Barbosa, C.M.M.; das Neves Santos, C.M. A critical review of mobile learning integration in formal educational contexts. In International Journal of Educational Technology in Higher Education; Springer: Berlin/Heidelberg, Germany, 2018; Volume 15.

5. Silva, H.S.; Bariani, R.C.; Kubo, H.; Leal, T.P.; Ilinsky, R.; Borges, T.; Faltin, K., Jr.; Ortolani, C.L.F. The Use of Technologies for Teaching Dentistry in Brazil: Reflections from an Integrative Review. Int. Educ. Stud. 2017, 10, 172. [CrossRef]

6. Cifuentes-Faura, J.; Obor, D.O.; To, L.; Al-Naabi, I. Cross-cultural impacts of COVID-19 on higher education learning and teaching practices in Spain, Oman, Nigeria and Cambodia: A cross-cultural study. J. Univ. Teach. Learn. Pract. 2021, 18, 135-151. [CrossRef]

7. Alismaiel, O.A. Using Structural Equation Modeling to Assess Online Learning Systems' Educational Sustainability for University Students. Sustainability 2021, 13, 13565. [CrossRef]

8. Raiman, L.; Antbring, R.; Mahmood, A. WhatsApp messenger as a tool to supplement medical education for medical students on clinical attachment. BMC Med. Educ. 2017, 17, 7. [CrossRef] [PubMed]

9. Li, R.; Meng, Z.; Tian, M.; Zhang, Z.; Ni, C.; Xiao, W. Examining EFL learners' individual antecedents on the adoption of automated writing evaluation in China. Comput. Assist. Lang. Learn. 2019, 32, 784-804. [CrossRef]

10. Saif, N.; Khan, I.U.; Khan, G.A. Investigating the Impact of Mobile Application on Learning among Teachers Based on Technology Acceptance Model (TAM). Glob. Educ. Stud. Rev. 2020, V, 45-54. [CrossRef]

11. Mutambara, D.; Bayaga, A. Rural-based Science, Technology, Engineering and Mathematics teachers' and learners' acceptance of mobile learning. SA J. Inf. Manag. 2020, 22, 1-10. [CrossRef]

12. Nikou, S.; Economides, A. Mobile-Based micro-Learning and Assessment: Impact on learning performance and motivation of high school students. J. Comput. Assist. Learn. 2018, 34, 269-278. [CrossRef]

13. Hoi, V.N.; Mu, G.M. Perceived teacher support and students' acceptance of mobile-assisted language learning: Evidence from Vietnamese higher education context. Br. J. Educ. Technol. 2021, 52, 879-898. [CrossRef]

14. Murphy, A.; Farley, H.; Dyson, L.E.; Jones, H. Mobile Learning in Higher Education in the Asia-Pacific Region; Springer: Singapore, 2017.

15. Gikas, J.; Grant, M.M. Mobile computing devices in higher education: Student perspectives on learning with cellphones, smartphones \& social media. Internet High. Educ. 2013, 19, 18-26.

16. Chung, C.-W.; Lee, C.-C.; Liu, C.-C. Investigating face-to-face peer interaction patterns in a collaborative Web discovery task: The benefits of a shared display. J. Comput. Assist. Learn. 2013, 29, 188-206. [CrossRef]

17. Liaw, S.-S.; Hatala, M.; Huang, H.-M. Investigating acceptance toward mobile learning to assist individual knowledge management: Based on activity theory approach. Comput. Educ. 2010, 54, 446-454. [CrossRef]

18. Dai, C.Y.; Chen, T.W.; Rau, D.C. The application of mobile-learning in collaborative problem-based learning environments. In Advances in Intelligent and Soft Computing; Springer: Berlin/Heidelberg, Germany, 2012; Advances in Intelligent and Soft Computing; Volume 127, pp. 823-828.

19. Alghazi, S.S.; Wong, S.Y.; Kamsin, A.; Yadegaridehkordi, E.; Shuib, L. Towards sustainable mobile learning: A brief review of the factors influencing acceptance of the use of mobile phones as learning tools. Sustainability 2020, 12, 10527. [CrossRef]

20. Shin, W.S.; Kang, M. The use of a mobile learning management system at an online university and its effect on learning satisfaction and achievement. Int. Rev. Res. Open Distrib. Learn. 2015, 16, 110-130. [CrossRef] 
21. Hwang, G.-J.; Chang, S.-C. Effects of a peer competition-based mobile learning approach on students' affective domain exhibition in social studies courses. Br. J. Educ. Technol. 2016, 47, 1217-1231. [CrossRef]

22. Sidik, D.; Syafar, F. Exploring the factors influencing student's intention to use mobile learning in Indonesia higher education. Educ. Inf. Technol. 2020, 25, 4781-4796. [CrossRef]

23. Lunt, T.; Curran, J. 'Are you listening please?' The advantages of electronic audio feedback compared to written feedback. Assess. Evaluation High. Educ. 2010, 35, 759-769. [CrossRef]

24. Taylor, J.; Dearnley, C.; Laxton, J.; Coates, C.; Treasure-Jones, T.; Campbell, R.; Hall, I. Developing a mobile learning solution for health and social care practice. Distance Educ. 2010, 31, 175-192. [CrossRef]

25. Alalwan, N.; Al-Rahmi, W.M.; Alfarraj, O.; Alzahrani, A.; Yahaya, N.; Al-Rahmi, A.M. Integrated three theories to develop a model of factors affecting students' academic performance in higher education. IEEE Access 2019, 7, 98725-98742. [CrossRef]

26. Schneckenberg, D.; Ehlers, U.; Adelsberger, H. Web 2.0 and competence-oriented design of learning-Potentials and implications for higher education. Br. J. Educ. Technol. 2011, 42, 747-762. [CrossRef]

27. Ada, M.B.; Stansfield, M.; Baxter, G. Using mobile learning and social media to enhance learner feedback: Some empirical evidence. J. Appl. Res. High. Educ. 2017, 9, 70-90.

28. Asghar, M.Z.; Barberà, E.; Younas, I. Mobile learning technology readiness and acceptance among pre-service teachers in Pakistan during the COVID-19 pandemic. Knowl. Manag. E-Learn. 2021, 13, 83-101.

29. Al-Rahmi, W.M.; Othman, M.S.; Yusuf, L.M. Using Social Media for Research: The Role of Interactivity, Collaborative Learning, and Engagement on the Performance of Students in Malaysian Post-Secondary Institutes. Mediterr. J. Soc. Sci. 2015, 6, 536. [CrossRef]

30. Chavoshi, A.; Hamidi, H. Social, individual, technological and pedagogical factors influencing mobile learning acceptance in higher education: A case from Iran. Telemat. Inform. 2019, 38, 133-165. [CrossRef]

31. McConatha, D.; Praul, M.; Lynch, M.J. Mobile learning in higher education: An empirical assessment of a new educational tool. Turk. Online J. Educ. Technol.-TOJET 2008, 7, 15-21.

32. Wang, M.; Shen, R.; Novak, D.; Pan, X. The impact of mobile learning on students' learning behaviours and performance: Report from a large blended classroom. Br. J. Educ. Technol. 2009, 40, 673-695. [CrossRef]

33. Lim, I. Reality for Malaysia's University Students: Online Learning Challenges, Stress, Workload; Possible Solutions for Fully Digital Future until Dec; Malay Mail: Petaling Jaya, Malaysia, 2020.

34. Almaiah, M.A.; Alamri, M.M.; Al-Rahmi, W.M. Analysis the Effect of Different Factors on the Development of Mobile Learning Applications at Different Stages of Usage. IEEE Access 2019, 8, 16139-16154. [CrossRef]

35. Kumar, B.A.; Chand, S. Mobile learning adoption: A systematic review. Educ. Inf. Technol. 2019, 24, 471-487. [CrossRef]

36. Al-Emran, M.; Mezhuyev, V.; Kamaludin, A. Technology Acceptance Model in M-learning context: A systematic review. Comput. Educ. 2018, 125, 389-412. [CrossRef]

37. Aremu, B.V.; Adeoluwa, O.V. M-learning: A Nexus for Adult Learners' Motivation and Readiness to Learn in Federal Universities at Southwest, Nigeria. J. Digit. Educ. Technol. 2021, 2, ep2201. [CrossRef]

38. Al-Rahmi, W.M.; Alkhalaf, S. An empirical investigation of adoption Big Data in higher education sustainability. Entrep. Sustain. Issues 2021, 9, 108-122. [CrossRef]

39. Alamri, M.M.; Almaiah, M.A.; Al-Rahmi, W.M. The Role of Compatibility and Task-Technology Fit (TTF): On Social Networking Applications (SNAs) Usage as Sustainability in Higher Education. IEEE Access 2020, 8, 161668-161681. [CrossRef]

40. Alamri, M.; Almaiah, M.; Al-Rahmi, W. Social Media Applications Affecting Students' Academic Performance: A Model Developed for Sustainability in Higher Education. Sustainability 2020, 12, 6471. [CrossRef]

41. Al-Rahmi, W.M.; Alzahrani, A.I.; Yahaya, N.; Alalwan, N.; Kamin, Y.B. Digital communication: Information and communication technology (ICT) usage for education sustainability. Sustainability 2020, 12, 5052. [CrossRef]

42. Arias, A.V.; Chalela, S.; Bermúdez-Hernández, J. A proposed model of e-learning tools acceptance among university students in developing countries. Educ. Inf. Technol. 2018, 24, 1057-1071. [CrossRef]

43. Davis, F.D.; Bagozzi, R.P.; Warshaw, P.R. User Acceptance of Computer Technology: A Comparison of Two Theoretical Models. Manag. Sci. 1989, 35, 982-1003. [CrossRef]

44. Alenazy, W.M.; Al-Rahmi, W.M.; Khan, M.S. Validation of TAM Model on Social Media Use for Collaborative Learning to Enhance Collaborative Authoring. IEEE Access 2019, 7, 71550-71562. [CrossRef]

45. Thakur, R. What keeps mobile banking customers loyal? Int. J. Bank Mark. 2014, 32, 628-646. [CrossRef]

46. Isa, W.A.R.W.M.; Lokman, A.M.; Mustapa, M.N.; Sah, I.N.M.; Hamdan, A.R.; Luaran, J.E. Exploring the Adoption of Blended Learning: Case of Mobile Learning. In Proceedings of the AIMS 2015 3rd International Conference on Artificial Intelligence, Modelling and Simulation, Kota Kinabalu, Malaysia, 2-4 December 2016; pp. 359-364.

47. Hong, W.; Liu, R.-D.; Ding, Y.; Jiang, R.; Sun, Y.; Jiang, S. A time-lagged study of two possible routes from personal innovativeness to life satisfaction in adolescents: Learning and social interaction on mobile phones. Pers. Individ. Differ. 2021, 182, 111075. [CrossRef]

48. Alhussain, T.; Al-Rahmi, W.M.; Othman, M.S. Students' Perceptions of Social Networks Platforms use in Higher Education: A Qualitative Research. Int. J. Adv. Trends Comput. Sci. Eng. 2020, 9, 2589-2603. [CrossRef] 
49. Agudo-Peregrina, Á.F.; Hernández-García, Á.; Pascual-Miguel, F.J. Behavioral intention, use behavior and the acceptance of electronic learning systems: Differences between higher education and lifelong learning. Comput. Hum. Behav. 2014, 34, 301-314. [CrossRef]

50. Lee, M.S. Effects of personal innovativeness on mobile device adoption by older adults in South Korea: The moderation effect of mobile device use experience. Int. J. Mob. Commun. 2019, 17, 682. [CrossRef]

51. Goodhue, D.L.; Thompson, R.L. Task-Technology Fit and Individual Performance. MIS Q. 1995, 19, 213-236. [CrossRef]

52. Al-Maatouk, Q.; Othman, M.S.; Aldraiweesh, A.; Alturki, U.; Al-Rahmi, W.M.; Aljeraiwi, A.A. Task-Technology Fit and Technology Acceptance Model Application to Structure and Evaluate the Adoption of Social Media in Academia. IEEE Access 2020, 8, 78427-78440. [CrossRef]

53. Qashou, A. Influencing factors in M-learning adoption in higher education. Educ. Inf. Technol. 2021, 26, 1755-1785. [CrossRef]

54. Al-Rahmi, A.M.; Shamsuddin, A.; Alturki, U.; Aldraiweesh, A.; Yusof, F.M.; Al-Rahmi, W.M.; Aljeraiwi, A.A. The Influence of Information System Success and Technology Acceptance Model on Social Media Factors in Education. Sustainability 2021, 13, 7770. [CrossRef]

55. Hizam, S.M.; Akter, H.; Sentosa, I.; Ahmed, W. Digital competency of educators in the virtual learning environment: A structural equation modeling analysis. IOP Conf. Series Earth Environ. Sci. 2021, 704, 12023. [CrossRef]

56. Chipangura, B. Conceptualizing Factors that Influence South African Students' Intention to Choose Mobile Devices as Tools for Learning. In Proceedings of the Innovative Technologies and Learning: Second International Conference, ICITL 2019, Tromsø, Norway, 2-5 December 2019; pp. 537-546.

57. Sánchez-Prieto, J.C.; Hernández-García, Á.; García-Peñalvo, F.J.; Chaparro-Peláez, J.; Olmos-Migueláñez, S. Break the walls! Second-Order barriers and the acceptance of mLearning by first-year pre-service teachers. Comput. Hum. Behav. 2019, 95, 158-167. [CrossRef]

58. Sayaf, A.M.; Alamri, M.M.; Alqahtani, M.A.; Al-Rahmi, W.M. Information and communications technology used in higher education: An empirical study on digital learning as sustainability. Sustainability 2021, 13, 7074. [CrossRef]

59. Al-Rahmi, W.M.; Yahaya, N.; Aldraiweesh, A.A.; Alturki, U.; Alamri, M.; Bin Saud, M.S.; Kamin, Y.; Aljeraiwi, A.A.; Alhamed, O.A. Big Data Adoption and Knowledge Management Sharing: An Empirical Investigation on Their Adoption and Sustainability as a Purpose of Education. IEEE Access 2019, 7, 47245-47258. [CrossRef]

60. Cheng, S.; Hwang, G.; Chen, C. From reflective observation to active learning: A mobile experiential learning approach for environmental science education. Br. J. Educ. Technol. 2019, 50, 2251-2270. [CrossRef]

61. Yorganci, S. Investigating Students' Self-Efficacy and Attitudes Towards the Use of Mobile Learning. J. Educ. Pract. 2017, 8, 181-185.

62. Ismail, I.; Gunasegaran, T.; Koh, P.P.; Idrus, R.M. Satisfaction of Distance Learners towards Mobile Learning in the Universiti Sains Malaysia. Malays. J. Educ. Technol. 2010, 10, 47-54.

63. Al-Rahmi, W.; Yahaya, N.; Alamri, M.; Aljarboa, N.A.; Kamin, Y.; Moafa, F.A. A Model of Factors Affecting Cyber Bullying Behaviors among University Students. IEEE Access 2018, 7, 2978-2985. [CrossRef]

64. Moafa, F.A.; Ahmad, K.; Al-Rahmi, W.; Yahaya, N.; Kamin, Y.; Alamri, M.M. Develop a Model to Measure the Ethical Effects of Students through Social Media Use. IEEE Access 2018, 6, 56685-56699. [CrossRef]

65. Al-Samarraie, H.; Teng, B.K.; Alzahrani, A.I.; Alalwan, N. E-learning continuance satisfaction in higher education: A unified perspective from instructors and students. Stud. High. Educ. 2018, 43, 2003-2019. [CrossRef]

66. Alyoussef, I.Y.; Alamri, M.M.; Al-Rahmi, W.M. Social media use (SMU) for teaching and learning in Saudi Arabia. Int. J. Recent Technol. Eng. 2019, 8, 942-946.

67. Hassanzadeh, A.; Kanaani, F.; Elahi, S. A model for measuring e-learning systems success in universities. Expert Syst. Appl. 2012, 39, 10959-10966. [CrossRef]

68. Chao, C.-M. Factors Determining the Behavioral Intention to Use Mobile Learning: An Application and Extension of the UTAUT Model. Front. Psychol. 2019, 10, 1652. [CrossRef] [PubMed]

69. Hamidi, H.; Chavoshi, A. Analysis of the essential factors for the adoption of mobile learning in higher education: A case study of students of the University of Technology. Telemat. Inform. 2018, 35, 1053-1070. [CrossRef]

70. Mutambara, D.; Bayaga, A. Determinants of mobile learning acceptance for STEM education in rural areas. Comput. Educ. 2020, 160, 104010. [CrossRef]

71. Al-Rahmi, W.M.; Yahaya, N.; Alturki, U.; Alrobai, A.; Aldraiweesh, A.A.; Omar Alsayed, A.; Kamin, Y.B. Social media-based collaborative learning: The effect on learning success with the moderating role of cyberstalking and cyberbullying. Interact. Learn. Environ. 2020, 1-14. [CrossRef]

72. Buabeng-Andoh, C. Predicting students' intention to adopt mobile learning. J. Res. Innov. Teach. Learn. 2018, 11, 178-191. [CrossRef]

73. Al-Rahmi, W.M.; Yahaya, N.; Alamri, M.M.; Alyoussef, I.Y.; Al-Rahmi, A.M.; Bin Kamin, Y. Integrating innovation diffusion theory with technology acceptance model: Supporting students' attitude towards using a massive open online courses (MOOCs) systems. Interact. Learn. Environ. 2019, 1-13. [CrossRef]

74. Chang, C.-T.; Hajiyev, J.; Su, C.-R. Examining the students' behavioral intention to use e-learning in Azerbaijan? The General Extended Technology Acceptance Model for E-learning approach. Comput. Educ. 2017, 111, 128-143. [CrossRef] 
75. Heflin, H.; Shewmaker, J.; Nguyen, J. Impact of mobile technology on student attitudes, engagement, and learning. Comput. Educ. 2017, 107, 91-99. [CrossRef]

76. Kukulska-Hulme, A. Mobile learning as a catalyst for change. Open Learn. J. Open Distance e-Learn. 2010, 25, 181-185. [CrossRef]

77. Winters, N. What is mobile learning. In Big Issues in Mobile Learning; University of Nottingham: Nottingham, UK, $2007 ;$ pp. 7-11.

78. Joo, Y.J.; Joung, S.; Shin, E.K.; Lim, E.; Choi, M. Factors Influencing Actual Use of Mobile Learning Connected with e-Learning. Int. J. Comput. Sci. Inf. Technol. 2014, 6, 169-176.

79. Hair, J.F.; Risher, J.J.; Sarstedt, M.; Ringle, C.M. When to use and how to report the results of PLS-SEM. In European Business Review; Emerald Group Publishing Ltd.: Bingley, UK, 2019; Volume 31, pp. 2-24.

80. Kim, C.; Mirusmonov, M.; Lee, I. An empirical examination of factors influencing the intention to use mobile payment. Comput. Hum. Behav. 2010, 26, 310-322. [CrossRef]

81. William, H.D.; Ephraim, R.M. The DeLone and McLean Model of Information Systems Success: A Ten-Year Update. J. Manag. Inf. Syst. 2003, 19, 9-30.

82. Habibi, A.; Yusop, F.D.; Razak, R.A. The role of TPACK in affecting pre-service language teachers' ICT integration during teaching practices: Indonesian context. Educ. Inf. Technol. 2020, 25, 1929-1949. [CrossRef]

83. Fornell, C.; Larcker, D.F. Evaluating Structural Equation Models with Unobservable Variables and Measurement Error. J. Mark. Res. 1981, 18, 39-50. [CrossRef]

84. Issaramanoros, E.; Khlaisang, J.; Pugsee, P. Auto Mechanic Students' Perceptions and Readiness toward Mobile Learning in Thailand. Int. J. Interact. Mob. Technol. 2018, 12, 28-42. [CrossRef]

85. Sayaf, A.M.; Alamri, M.M.; Alqahtani, M.A.; Alrahmi, W.M. Factors Influencing University Students' Adoption of Digital Learning Technology in Teaching and Learning. Sustainability 2022, 14, 493. [CrossRef]

86. Bere, A. Applying an extended task-technology fit for establishing determinants of mobile learning: An instant messaging initiative. J. Inf. Syst. Educ. 2018, 29, 239-252.

87. Azizi, S.M.; Khatony, A. Investigating factors affecting on medical sciences students' intention to adopt mobile learning. BMC Med. Educ. 2019, 19, 381. [CrossRef] [PubMed]

88. Saroia, A.I.; Gao, S. Investigating university students' intention to use mobile learning management systems in Sweden. Innov. Educ. Teach. Int. 2019, 56, 569-580. [CrossRef]

89. Huang, J.H.; Lin, Y.R.; Chuang, S.T. Elucidating user behavior of mobile learning: A perspective of the extended technology acceptance model. Electronic Library 2007, 25, 585-598. [CrossRef]

90. Faura-Martínez, U.; Lafuente-Lechuga, M.; Cifuentes-Faura, J. Sustainability of the Spanish university system during the pandemic caused by COVID-19. Educ. Rev. 2021, 1-19. [CrossRef]

91. Neuwirth, L.S.; Jović, S.; Mukherji, B.R. Reimagining higher education during and post-COVID-19: Challenges and opportunities. J. Adult Contin. Educ. 2020, 27, 141-156. [CrossRef]

92. Raza, S.A.; Umer, A.; Qazi, W.; Makhdoom, M. The Effects of Attitudinal, Normative, and Control Beliefs on M-Learning Adoption Among the Students of Higher Education in Pakistan. J. Educ. Comput. Res. 2017, 56, 563-588. [CrossRef]

93. Alrasheedi, M.; Capretz, L.; Raza, A. Management's Perspective on Critical Success Factors Affecting Mobile Learning in Higher Education Institutions-An Empirical Study. J. Educ. Comput. Res. 2015, 54, 253-274. [CrossRef]

94. Viberg, O.; Andersson, A.; Wiklund, M. Designing for Sustainable Mobile Learning-Re-Evaluating the Concepts "Formal" and "Informal"; Taylor \& Francis: Abingdon, UK, 2021; Volume 29, pp. 130-141.

95. Bradley, C.; Holley, D. Empirical research into students' mobile phones and their use for learning. In Innovations in Mobile Educational Technologies and Applications; IGI Global: Hershey, PA, USA, 2013; pp. 318-333.

96. Gupta, N.; Irwin, J.D. In-class distractions: The role of Facebook and the primary learning task. Comput. Hum. Behav. 2016, 55, 1165-1178. [CrossRef]

97. Basak, S.K.; Wotto, M.; Bélanger, P. E-learning, m-learning and d-learning: Conceptual defnition and comparative analysis E-Learn. Digit. Media 2018, 15, 191-216. [CrossRef]

98. Shi, C.; Yu, L.; Wang, N.; Cheng, B.; Cao, X. Efects of social media overload on academic performance: A stressor- strain-outcome perspective. Asian J. Commun. 2020, 30, 179-197. [CrossRef]

99. Sarwar, B.; Zulfqar, S.; Aziz, S.; Chandia, K.E. Usage of social media tools for collaborative learning: The efect on learning success with the moderating role of cyberbullying. J. Educ. Comput. Res. 2019, 57, 246-279. [CrossRef]

100. Ali, W. Online and Remote Learning in Higher Education Institutes: A Necessity in light of COVID-19 Pandemic. High. Educ. Stud. 2020, 10, 16-25. [CrossRef] 